\title{
Persecution of believers as a systemic feature of the Soviet regime
}

\author{
Lyubov Soskovets $^{1, \mathrm{a}}$, Sergei Krasilnikov ${ }^{2}$, and Dina Mymrina ${ }^{1}$ \\ ${ }^{1}$ Tomsk Polytechnic University, 634050 Lenin Avenue, 30, Tomsk, Russia \\ ${ }^{2}$ Novosibirsk State University, Pirogova st. 2, Novosibirsk 630090, Russia
}

\begin{abstract}
The article focuses on the anti-religious policy of the Soviet Union adopted in relation to believers and religious organizations. The reasons for the persecution of religion, churches and believers, such as the conceptual framework of Marxist ideology, desire for total power, and creation of an ideocratic state are analyzed. The main stages of the anti-religious campaign led by the Bolshevik government are determined. Major anti-religious practices, such as legal restriction of all forms of religious life, discrimination against the clergy and believers, atheist education and anti-religious propaganda work are studied. It may be concluded that persecution of believers is a systemic feature of a totalitarian regime.
\end{abstract}

\section{Introduction}

Discrimination against certain population groups in society is an ancient, widely practiced and widely occurring phenomenon that continues to exist and affect the life of a person. People's freedoms and rights are often violated upon various pretexts; the nature of violation appears to be different and, thus, discrimination manifests itself in many forms. One of the most common reasons for discrimination can be people's religious beliefs. Persecution of people of different faiths and different religions, religious intolerance, and religious conflicts seem to be some of the problems the international community should be concerned with.

The article attempts to analyze the unique experience of discrimination in the Soviet Union where discrimination affected the lives of all believers and existed in most extreme forms. Those include restriction of all religious activities, struggle against church and all religious institutions, attempts to eradicate the foundations of religious beliefs. It is well known that the Soviet government and the Communist Party had a goal to destroy all religious organizations, for this reason they persecuted believers of different confessions. Even before the October Revolution there was no religious freedom in Russia as well as there was no equality of religions. Strangely, but it appears to be that it is due to the systematic anti-church terror in the Soviet Union that all the faiths were made equal, though the equality was mainly achieved through violation of rights and freedoms.

Persecution of believers in the Soviet Union is said to be one of the issues which are widely considered by both
Russian and foreign historians. The issue was analyzed from various viewpoints: state policies toward religions and churches [1-2], state-church relationships [3], the future of the Russian Orthodox Church [4-7], Catholic and Lutheran churches [8], Protestantism [9] and other religions in the USSR [10].

Discriminatory practices of the Soviet government toward religions, churches, religious associations and believers were also studied outside the Soviet Union [11], and it should be noted that it had been done long before Russian researchers were able to do that. W. Fletcher [12], J. Ellis [13], N. Davis [14], D. Pospielovsky [15], having focused on the history of the Russian Orthodox Church in the Soviet period, presented a vast picture of religious persecution in the USSR [16]. Acts of discrimination against Protestants, living in the Soviet Union, were analyzed by M. Bourdeaux [17], W. Sawatsky [18].

\section{Materials and methods}

Methods and approaches used in the study of religious discrimination in the Soviet Union include general scientific (analysis, synthesis, induction, deduction, systemic approach etc.) and general historical (historicalgenetic, comparative, chronological, typological etc.) methods, which allow us to determine the causes and roots of religious persecution in the Soviet Union, describe the anti-religious policy as a systemic phenomenon, reveal the main anti-religious practices of the Soviet government, and identify the consequences and effects of the discrimination policy.

\footnotetext{
a Corresponding author: ivitca56@mail.ru
} 


\section{Results and discussion}

It appears that there could be several theories that would explain the nature of the Soviet anti-religious campaign, its intensity, permanent and all-inclusive character, the diversity of its forms and manifestations, thus, would clarify the reasons why the clergy, believers and their associations, religion as a form of social consciousness were heavily persecuted by the Bolsheviks. In theory, the campaign was based on Marxism-Leninism, which regarded religion as one of the most sophisticated forms of idealistic views, and, thus, could represent a significant threat to the Revolution and Socialism. Having said that religion is "the opiate of the people" and "a sort of spiritual booze", the founders of MarxismLeninism clearly identified the main function of religion in society. Asserting the earthly roots of religion, $\mathrm{K}$. Marx, F. Engels and V. Lenin believed that the roots would be undermined while building up a socialist society, and thought that systematic work on atheistic education could help to achieve the goal. Thus, discrimination against religions, their institutions and religious believers was claimed to become a very important phase in the struggle for Socialism-Communism; it was also believed that any way of achieving the goal was acceptable, thus discrimination against people was seen as one of those ways.

The nature of the violent anti-religious and antichurch policy could be also explained by other factors. It should be remembered that most of the Bolshevik literature and propaganda negatively criticized the role of religion and church in the history of the Russian state and society. Churches, first of all, the Russian Orthodox Church, were viewed as part of the former political and ideological system, and, therefore, had to be destroyed. Besides, the Communist Party, seeking the totality of power and implanting ideocracy, uncompromisingly fought its ideological opposition. Religion and believers were seen as its most obvious opponents.

The anti-religious campaign of the Soviet Union can be divided into several phases. The criteria for the division are various: specific objectives, the intensity of persecution of believers and religious organizations, primary targets of persecution, causes of discrimination, socio-political processes that caused discrimination, dominant anti-religious practices etc.

It is often mentioned that in the first years after the October Revolution, the Bolsheviks' Red Guard attacked religious organizations, seeing churches, primarily the Russian Orthodox Church, as ideological and political opponents. During that period, the economic base of the church was destroyed; its institutional and organizational base was seriously affected; persecution, arrests and executions, aimed at intimidating the clergy and believers, were widely spread and effective.

The next phase of the anti-religious campaign was the period of the New Economic Policy when the Bolsheviks, attempting to retain power and support in society, had to stop persecution of religious organizations or, to be exact, make it less severe. The Communist Party and the Soviet government focused their efforts on promoting materialist ideals and atheist education, seeking to transform the minds of believers.

Another period of intense and furious attacks on religious organizations and believers was the period of collectivization, which could be seen as one of the causes of the religious persecution. Measures that were taken to restrain the activity of religious associations in the period were all-encompassing as they included persecution, repressions, large-scale propaganda work whose aim was to expose the weaknesses of religion, the clergy and believers. Terror was ideologically justified: the clergy and believers were viewed as open and hidden enemies of the construction of a socialist state, industrialization and collectivization. They were accused of sabotaging, aiding "kulaks", working for foreign intelligence agencies, assisting the fascist underground and "the fifth column". Persecution of the clergy and ordinary believers irrespective of what religion they had was widespread: a significant number of lawsuits were brought against the clergy and churches, many people were executed without charge or trial. By the end of the 1930s, churches and religious organizations had been virtually destroyed: they had been deprived of their property, the church staff and the assets had been arrested, and part of the clergy had been shot dead.

During the World War II, the Soviet Union had to ease its attacks on the church. It was allowed to restore some of the bodies of the Russian Orthodox Church and several other churches. Believers were permitted to attend religious services. However, I. Stalin's policy of liberalization in relation to some of the religious organizations did not last long and was limited in its character.

Since the late 1950s, under N. Khrushchev, the Soviet government initiated a new campaign against religion, churches, and believers. Again, by means of legislation, religious practices were restricted, religious believers were persecuted and church property was confiscated. This time, it was claimed that the antireligious campaign was undertaken in order to build a Communist society, in which, according to the Party's opinion, there was no place for religion, church, and religious believers.

During the last phase (the mid-1960s, the end of the 1980s), there was no mass persecution of religious organizations, the clergy, and believers. However, no favorable conditions for their religious activities were created. The Soviet government renewed its antireligious propaganda, introducing atheist education in schools and universities [19]. Thus, throughout its history, the Soviet government was constantly involved in various anti-religious activities.

Religious persecution in Soviet Russia and the Soviet Union was not only constant, but it also existed in various forms. First of all, from the very beginning of its existence, the Soviet regime started to form a legal basis that could weaken the influence of churches on people, and would adversely affect religious associations in a number of ways.

The first most important legislation act was the Decree "On the Separation of Church from State and School from Church" issued on January 23, 1918 [20]. 
The Decree appeared to be liberal: it declared the equality of all religions and guaranteed the freedom of conscience, which was treated as a human right to profess a religion or not to profess any religion or belief. However, the fundamental provision of the legislation act appeared to have been absolutely distorted. Practically from the very beginning, the Soviet government was seen closing down churches and confiscating church property, which could help to achieve the revolutionary aims. Other cases of persecution included aggressive behaviours during searches in churches, removing icons from public places, which was often accompanied by "unnecessary attacks". The clergy were often legally obliged to clean streets and squares; believers were not allowed to voluntarily donate money to their church etc.

Apart from the Decree of 1918, there was another document which regulated the state-church relations and the activity of religious associations in the country, the Decree of the All-Russian Central Executive Committee and the Council of People's Commissars of the Russian Soviet Federated Socialist Republic (April 8, 1929) "On Religious Associations" [21].

The 1929 legislation contained a number of restrictions and prohibitions on the activity of a religious association. The list of prohibited activities was extensive; for example, no mutual benefit societies were allowed; it was prohibited to donate charity, create cooperatives and production associations, provide financial support to the members of an association, conduct prayer-meetings for children, the youth or women, carry out a catechetical activity etc. In other words, henceforth religious communities and religious decision-making structures were legally limited in their competences.

Besides, believers, the clergy, heads of religious organizations as well as officials were declared to bear extrajudicial administrative responsibility before the state, which was often thought as one of the reasons to continue anti-religious campaigns against church and other religious organizations. Struggling with church and believers, seeking to discredit them and eradicate them, the authorities often justified their actions by saying that religious activities and behaviour of believers did not comply with the Soviet legislation on cults.

The law required religious associations to register and defined the criteria that could be used to determine the status of a religious organization. Thus, religious organizations were given little or no legal status, which means the following: some of them were allowed to exist (though their activity was limited), while the majority were called illegal. The latter were thought to require special attention and more decisive and concrete measures to deal with. In this way, religious persecution was legitimized.

It appears that the Soviet Union established various mechanisms of state control, persecution and suppression of religious organizations. The government bodies most notorious for their active participation in the anti-religious struggle of the Soviet state were the 8th (then known as the 5th) Department under the Council of People's Commissars, and the Commission for the
Affairs of Cults, which acquired the status of the Standing Committee under the Central Executive Committee of the Russian Soviet Federative Socialist Republic. Still, all major decisions concerning statechurch relations were made by the Orgburo and the Politburo of the Central Committee and the AntiReligious Commission of the Central Committee of the All-Union Communist Party of the Bolsheviks (1922 1929).

An important (if not decisive) role in the suppression and destruction of religious organizations was played by the Soviet punitive agencies, such as the 6th Department of the Joint State Political Directorate under the Council of People's Commissars of the USSR (also known as the OGPU), which was created to combat the counterrevolutionary force associated with religion, and then the NKVD (the People's Commissariat of Internal Affairs) whose main function was to protect the Soviet state from its enemies. It is the NKVD that is claimed to have actively participated in the persecution of the clergy and believers. The most common forms of punishment imposed on that group of people were arrests, long term imprisonment, exile, and prison camps. They were all used during the whole Soviet period, except for execution which had not been practised since the 1940s. It should be mentioned that millions of believers were severely persecuted during this period.

Apart from the All-Union Communist Party, the OGPU (the NKVD), there were 2 more socio-political organizations in the Soviet Union that were involved in the anti-religious struggle of the 1920s - 1930s: the Komsomol and the League of Militant Atheists which, in fact, appeared to become the major striking force of the regime in the anti-religious campaign. In 1943 - 1944, the Council for Affaires of the Russian Orthodox Church and the Council for the Affairs of Religious Cults were set up under the Council of People's Commissars (later, under the Council of Ministers of the USSR). Being mandated to organize anti-religious activities, these bodies acted as the executors of the State will and the Party interests in the religious sphere.

Last but not least, large-scale, permanent, allinclusive and various anti-religious propaganda work and agitation which held a particular place among other discriminatory practices. Both of them were aimed at insulting and degrading religion, church and religious believers. The anti-religious campaign was conducted via all state and public institutions: schools and universities, the mass media, publishing houses, culture and leisure centres, artists' unions, the Komsomol, and trade unions. Violating the principle of freedom of conscience, millions of atheists revealed, ridiculed and demonized everything related to religion, faith, church, religious history and tradition, church service, and believers' outlook; not to mention that it was done on a daily basis through various forms of media. The clergy and believers were often portrayed as enemies of the Soviet state, and, thus, were treated as counterrevolutionaries, saboteurs, bigots, spies, at best, misguided and deceived people, who needed to be exposed, revealed, punished, or reeducated. 


\section{Conclusion}

Lastly, it may be concluded that religious persecution in the USSR was characterized by several important features:

- it was permanent, as it did not stop during the whole Soviet period;

- it was total, i.e. people of various (all) religious beliefs were targeted for persecution;

- it took different, frequently violent forms;

- it was committed by the government, the Party and a number of social bodies;

- its aim was to eradicate religion, church, and all believers in the country.

The phenomenon of religious persecution in the Soviet Union can be explained by the fact that the Communist state, being totalitarian and ideocratic by nature, sought to quickly destroy religion in the country as it was often viewed as a competitor to the Bolshevik (Communist) ideology. This explains the uncompromising attitude towards religious believers who were thought to bear opposing views on the world, society and human destiny. Thus, discrimination against believers can be seen as a systemic feature of the political regime.

As a result of a deliberate policy of the authorities, religion was forced out of the public sphere and people's consciousness; churches were destroyed, the clergy lost their jobs, religious believers were turned into outcasts and were deprived of their right to believe in their God. People, openly speaking about their faith and belief in God, were often misunderstood and rejected by the atheist society.

\section{Acknowledgment}

This work is funded within the framework of realization of Strategic Programme on National Research Tomsk Polytechnic University Competitiveness Enhancement in the Group of Top Level World Research and Academic Institutions.

\section{References}

1. M. Odintsov, State and church in Russia: the XXth century (Moscow: Luch, 1994)

2. L. Soskovets, Religious organizations and believers in the Soviet Union (Tomsk: TML-Press, 2008)

3. Yu. Bakaev, State and religion: the history of relations (1917 - 1941) (Khabarovsk: Khabarovsk State Technical University, 2002)

4. D. Konstantinov, The persecuted church: Russian Orthodox Church in the USSR (Moscow: Association of Authors and Publishers, 1999)

5. M. Shkarovsky, Russian Orthodox Church under Stalin and Khrushchev: state-church relations in the USSR in 1939 - 1964 (Moscow: Krutitskoye Podvorie. 2005)

6. O. Vasilieva, Russian Orthodox Church in Soviet state policies, 1943 - 1948 (Moscow: the Institute of
Russian History of the Russian Academy of Sciences, 2001)

7. A Beglov, In search of "sinless catacombs". The church underground in the USSR (Moscow: «Arefa», 2008)

8. O. Litsenberger, The Roman Catholic Church in Russia: history and legal status (Saratov: Volga Region Academy for Public Administration., 2001)

9. T. Nikolskaya, Russian Protestantism and state power in 1905 - 1991 (Saint Petersburg, 2009)

10. M Krapivin, A.Leikin and A. Dalgatov, Destiny Christian sectarianism in Soviet Russia (1917 - the end of the 1930s) (Saint Petersburg: Saint Petersburg State University, 2003)

11. W. Kolarz, Religion in the Soviet Union (London: Macmillan, 1961)

12. W. Fletcher, The Russian Orthodox Church underground, 1917 - 1970 (Oxford: University press, 1971)

13. J. Ellis, The Russian Orthodox Church: a contemporary history (Bloomington: Indiana University Press, 1986)

14. N. Davis, A long walk to church. A contemporary history of Russian Orthodoxy (Boulder and Oxford: Westview Press Inc, 1995)

15. D. Pospielovsky, Russian Orthodox Church in the 20 century (Moscow: Respublika, 1995)

16. J. Anderson., European history quarterly, 44 (2), 382-384 (2014)

17. M. Bourdeaux, Religious ferment in Russia. Protestant opposition to Soviet religious policy (London: Macmillan, N.-Y.: St. Martin's press, 1968)

18. W.Sawatsky, Soviet Evangelicals: since Word War II (Scottdale: PA. Herald Press, 1981)

19. V. Smolkin-Rothrock, Russ. Rev., 73, 2 (2014).

20. About religion and church. A collection of the classics of Marxism-Leninism, documents of the CPSU and the Soviet state (Moscow: Politizdat, 1981)

21. Decree of the All-Russian Central Executive Committee and the Council of People's Commissars respecting religious association, April 8, 1929, Russian Orthodox Church in the Soviet period (Moscow: Propilei, Book 1, 1995) 